\title{
Kedudukan Anak Perempuan dalam Sistem Pewarisan pada Adat Ulun Lampung Saibatin di Kecamatan Pesisir Tengah Kabupaten Pesisir Barat
}

\section{Girls Position of The Ulun Lampung Saibatin Custom Inheritance System in Pesisir Tengah District, Pesisir Barat Regency}

\author{
Bina Yusha ${ }^{1 *}$, Risma Margaretha Sinaga ${ }^{2}$, Sugeng Widodo ${ }^{3}$ \\ Pascasarjana Pendidikan IPS Universitas Lampung, Indonesia \\ 1yushaarfa@gmail.com; 2sinaga_rmargaretha@yahoo.com; ${ }^{3}$ sugeng_geografi@unila.ac.id \\ *Penulis koresponden
}

\begin{abstract}
Ulun (orang) Lampung menganut sistem kekerabatan patrilineal, yakni menarik garis keturunan kebapakan, sangat mementingkan seorang anak laki-laki dalam anggota keluarganya sebagai penerus keturunan. Laki-laki dalam adat ulun Lampung Saibatin memiliki kedudukan yang tinggi dalam prihal penerimaan warisan dibandingkan dengan perempuan. Perempuan hanya sebagai pemelihara harta warisan dan tidak berhak memiliki. Dalam penelitian ini bertujuan untuk memaparkan kedudukan perempuan dan menjelaskan jenis harta warisan yang diperolehnya berdasarkan kedudukannya dalam sistem pewarisan adat ulun Lampung Saibatin. Penelitian ini menggunakan pendekatan kualitatif dengan jenis penelitian etnografi dan menggunakan model interaktif Miles dan Huberman. Data dikumpulkan melalui wawancara mendalam dan observasi. Hasil penelitian menunjukkan kedudukan anak perempuan dalam sistem pewarisan bukan sebagai ahli waris meskipun ia sebagai anak kandung, anak tiri, dan anak angkat serta sebagai waris balu (janda) dalam sebuah keluarga. Kedudukan bukan sebagai ahli waris ini berdampak pada jenis harta yang akan dimilikinya dan keturunannya kelak. Jenis harta materiil dan immaterill di peroleh anak perempuan jika ia memiliki gelar adat dalam masyarakat. Namun, harta yang diperoleh anak perempuan pada umumnya hanya mendapatkan harta berupa materiil saja dengan jenis harta bawaan.
\end{abstract}

Kata Kunci: Kedudukan perempuan, sistem pewarisan, adat ulun Lampung, saibatin

\begin{abstract}
Ulun (people) Lampung adhere to a patrilineal kinship system, which is to draw a fatherly lineage, attach great importance to a boy in a family member as a descendant. Men in the ulun Lampung Saibatin tradition have a higher position in terms of receiving inheritance compared to women. Women are only custodians of inheritance and have no right to own them. This study aims to describe the position of women and to explain the types of inheritance they receive based on their position in the ulun Lampung Saibatin customary inheritance system. This study uses a qualitative approach with ethnographic research type and uses the interactive model of Miles and Huberman. Data were collected through in-depth interviews and observations. The results showed that the position of girls in the inheritance system was not as heirs even though they were biological children, stepchildren, and adopted children as well as inheritors of a balu (widow) in a family. The position of not being an heir has an impact on the types of assets she will have and her future descendants. The type of material and immaterial assets is obtained by a girl if she has a customary title in the community. However, the assets obtained by girls generally only get material assets with the types of assets.
\end{abstract}

Keywords: Position of women, inheritance system, traditional of Lampung, Saibatin People

\section{Pendahuluan}

(c) 2021 oleh Bina Yusha, Risma Margaretha Sinaga, Sugeng Widodo.

Artikel ini terbuka untuk umum (open access) dan dapat didistribusikan sesuai dengan aturan di dalam Lisensi Creative Commons Attribution (CC BYNC) di https://creativecommons.org/licenses/by-nc-sa/4.0/. 
Perempuan merupakan sosok yang seharusnya memiliki kesempatan dan hak yang sama seperti kaum laki-laki. Kesempatan dan hak sebagai manusia yang mampu berperan dan berpartisipasi dalam kegiatan Politik, Ekonomi, Sosial Budaya, Pertahanan dan Keamanan Nasional, serta kesamaan dalam menikmati hasil pembangunan serta dalam hal pewarisan pada adat- adat yang berlaku di seluruh Indonesia. Nugroho (2016) menyatakan bahwa hukum waris adat yakni hukum waris yang berlaku bagi penduduk Indonesia asli atau pribumi. Namun, beberapa daerah di Indonesia yang masih menjunjung tinggi sistem patriarki yang menempatkan laki-laki sebagai pemegang kekuasaan utama dan mendominasi dalam peran kepemimpinan politik, otoritas moral, hak sosial, dan penguasaan properti. Hal itu sejalan dengan Sakina (2019) yang mengatakan bahwa sejak masa lampau, budaya masyarakat dunia telah menempatkan laki-laki pada hirarki teratas, sedangkan perempuan menjadi kelas nomor dua. Sistem patriarki seperti ini berdampak pada timbulnya berbagai permasalahan sosial di Indonesia yang membelenggu kebebasan dan melanggar hak-hak perempuan di berbagai ruang lingkup. Salah satunya adalah ruang lingkup keluarga. Dalam ruang lingkup keluarga masih banyak perempuan yang tidak dilibatkan dalam hal pengambilan keputusan dan pewarisan. Daerah di Indonesia yang sampai sekarang menganut sistem ini adalah masyarakat Lampung, khususnya pada ulun (orang) Lampung Saibatin di wilayah Krui Kecamatan Pesisir Tengah Kabupaten Pesisir Barat Lampung.

Ulun Lampung Saibatin hanya memperbolehkan laki-laki dalam pengambilan keputusan, sedangkan perempuan hanya menerima putusan tersebut. Sama halnya dalam sistem pewarisan, Menurut Haar (1990) hukum waris adat adalah aturan-aturan hukum yang mengatur cara bagaimana dari abad ke abad penerusan dan peralihan dari harta kekayaan yang berwujud dan tidak berwujud dari generasi pada generasi berlaku. Hadikusuma (2003) juga mengemukakan bahwa hukum waris adat adalah hukum adat yang memuat garis-garis ketentuan tentang sistem dan asas-asas hukum waris, tentang harta warisan, pewaris, dan waris serta cara bagaimana harta warisan itu dialihkan penguasaan dan pemilikannya dari pewaris kepada waris. Berdasarkan hukum waris berdasarkan adat Ulun Lampung Saibatin, mereka lebih mengistimewakan anak lakilaki dibandingkan anak perempuan. Artinya, hanya anak laki-laki saja yang berhak menerima warisan, sedangkan perempuan tidak. Hal ini jelas akan berdampak pada perkawinan yang tidak memiliki anak lakilaki dan hanya memiliki anak perempuan (mutung/cadang atau tidak memiliki penurus keturunan).

Berdasarkan hasil wawancara dengan bapak Faisol Amirillah selaku kepala adat Marga La`ay, ia mengungkapkan pembagian waris pada adat ulun Lampung Saibatin lebih menitikberatkan kepada anak laki-laki saja, seperti yang tertera dalam Gambar 1.

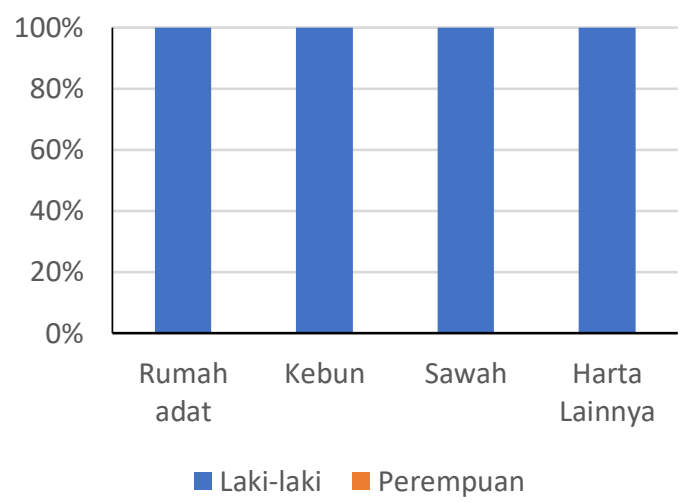

Gambar 1. Grafik pembagian waris pada adat ulun Lampung Saibatin

Sumber: Dokumentasi Pribadi Tahun 2020

Gambar 1 menunjukkan jenis harta warisan menurut hukum adat ulun Lampung Saibatin, anak laki-laki mendapatkan jenis harta berupa Lamban Tuha (rumah tua), harta tanah, dan harta benda lainnya sedangkan anak perempuan tidak mendapatkan apa-apa. Pembagian harta warisan ini hidup dan berjalan karena ia menjelmakan kebiasaan dan perasaan hukum yang nyata dari rakyat, Soepomo (1980). Hal ini dikarenakan anak laki-laki dianggap mempunyai tanggung jawab penuh untuk memelihara, membina, dan mempertahankan kehidupan yang layak bagi seluruh anggota keluarga, baik orang tua atau adik-adiknya yang belum mampu hidup mandiri. Sedangkan perempuan dianggap 
tidak memiliki tanggung jawab terhadap anggota keluarga.

Padahal saat ini, banyak perempuan (istri) tidak hanya diam di rumah menjadi ibu rumah tangga. Banyak dari mereka yang bekerja dan menghasilkan uang untuk memenuhi kebutuhan keluarga. Ada juga istri yang membawa harta ke dalam pernikahan, baik karena usahanya sendiri sebelum menikah atau pemberian dari orang tua mereka. Sehingga, dapat dikatakan istri juga berkontribusi dalam pembentukan harta bersama. Kontribusi istri terhadap pembentukan harta keluarga akan memengaruhi kontrol atas harta tersebut, sehingga harta yang ada dalam keluarga tidak lagi hanya menjadi "harta suami", tetapi juga "harta istri". Dengan kata lain, sang istri juga merupakan pewarisnya.

Berdasarkan pemaparan di atas, bahwa seharusnya perempuan juga memiliki hak atas warisan yang sama dengan laki-laki terlepas ia memiliki kedudukan dalam adat atau tidak. Dalam penelitian ini akan memaparkan mengenai bagaimana kedudukan anak perempuan ulun Lampung Saibatin dalam sistem pewarisan dan apa sajakah jenis harta warisan yang ia peroleh berdasarkan kedudukan tersebut sesuai dengan hukum adat yang berlaku pada ulun Lampung Saibatin.

\section{Metode}

Jenis penelitian yang digunakan dalam penelitian ini adalah etnografi dengan desain pendekatan kualitatif deskriptif. Etnografi merupakan salah satu pendekatan dalam metode penelitian kualitatif yang berusaha mengeksplor suatu budaya masyarakat. Etnografi digunakan untuk meneliti perilakuperilaku manusia berkaitan dengan perkembangan teknologi komunikasi dalam setting sosial dan budaya tertentu (Bungin, 2003). Prosedur siklus penelitian etnografi mencakup enam langkah yaitu:

(1) Memilih proyek etnografi,

(2) Mengajukan pertanyaan etnografis,

(3) Mengumpulkan data etnografi,

(4) Membuat catatan etnografis,

(5) Menganalisis data etnografi,

(6) Menulis laporan.

Lokasi penelitian ini telah dilakukan di Krui Kecamatan Pesisir Tengah Kabupaten Pesisir Barat. Lokasi ini dipilih karena ulun Lampung Saibatin di daerah ini merupakan penduduk asli Lampung Saibatin yang masih memegang teguh adat dan kebiasaannya. Variabel yang digunakan dalam penelitian ini adalah kedudukan anak perempuan dalam sistem pewarisan ulun Lampung Saibatin. Kedudukan ini diperoleh dengan dua cara yakni diperoleh sejak ia lahir (ascribed status) dan kedudukan yang diperoleh atas usahanya sendiri (achieved status). Kriteria informan dalam peneliatian ini adalah:

1. Kepala marga/sesepuh adat yang bertugas memberikan informasi kedudukan anak perempuan dalam sistem pewarisan

2. Anak perempuan keturunan marga/adat ulun Lampung Saibatin

3. Anak perempuan sebagai warga Lampung Saibatin yang berada di Kecamatan Pesisir Barat.

Data dikumpulkan melalui wawancara mendalam dan observasi. Wawancara mendalam dilakukan dengan tanya jawab menggunakan pedoman wawancara yang telah disiapkan terlebih dahulu untuk mendukung didapatkannya data yang valid dan relevan untuk menunjang hasil penelitian yang sesuai dengan tujuan penelitian. Observasi dilakukan dalam tiga tahap. Pertama, observasi deskriptif dengan menggambarkan secara luas situasi sosial yang terjadi di lokasi penelitian. Kedua, observasi terfokus dilakukan untuk menemukan kategori jenis harta warisan yang dimiliki oleh anak perempuan. Ketiga, observasi selektif untuk mencari perbedaan antar kategori seperti jenis harta pusaka, harta bawaan, harta perkawinan, dan hak yang didapatkan dari masyarakat. Selain itu, peneliti juga menggunakan buku dan dokumen yang terkait dengan rumusan masalah sebagai (bahan acuan) pengumpulan data lainnya. Analisis data dilakukan dengan cara mengorganisasi data yang diperoleh kedalam sebuah kategori, menjabarkan data kedalam unitunit, menganalisis data yang penting, menyusun atau menyajikan data yang sesuai dengan masalah penelitian dalam bentuk laporan dan membuat kesimpulan agar mudah untuk dipahami. Peneliti menggunakan model interaktif dari Miles dan Huberman untuk menganalisis data hasil penelitian. Teknik analisis data ini meliputi tiga komponen analisis yaitu pengumpulan data, penyajian data dan reduksi data 


\section{Hasil dan Pembahasan}

Sistem Kekerabatan ulun Lampung Saibatin

Ulun Lampung Saibatin mengenal sistem kekerabatan dengan istilah ke-marga-an. Sistem kekerabatan yang dipakai adalah patrilineal yang lebih mengutamakan alur keturunan berasal dari pihak ayah. Dari enam belas margayang dikenal oleh ulun Lampung Saibatin, Ada lima marga yang menjadi informan dalam penelitian yaitu marga Ulu Krui, marga Bandar, marga La`ay, marga Pasar, dan marga Pedada. Namun, tidak semua marga menganut sistem kekrabatan patrilineal. Seperti marga Pasar yang menganut sistem kekerabatan matrilineal karena bukan warga asli Lampung Saibatin melainkan warga pendatang.

\section{Sistem Pewarisan pada adat ulun Lampung Saibatin}

Pewarisan adalah kaidah hukum yang mengatur antara pewaris dengan ahli waris atas harta warisan yang ditinggalkan, baik setelah pewaris meninggal ataupun selagi pewaris itu masih hidup. Sistem pewarisan pada adat ulun Lampung Saibatin harus dilakukan agar sah dimata hukum dalam mengubah hak dan kewajiban, serta besarnya perolehan harta warisan dari pewaris ke ahli waris. Sistem pewarisan yang berlaku pada ulun Lampung Saibatin yang menempati wilayah Kecamatan Pesisir Tengah adalah sistem pewarisan mayorat laki-laki dan sistem mayorat perempuan, dengan proses pewarisan dilakukan dengan tiga cara yakni:

Dilakukan sebelum pewaris wafat.

1. Penerusan atau pengalihan

Proses pewarisan dengan cara penerusan atau pengalihan ( $d i$ jengken) dan berpesan/berwasiat/beramanat dilakukan saat pewaris masih hidup. Proses pewarisan dengan cara ini berlaku setelah pewaris berumur lanjut dan anak tertua laki-laki dan adik-adiknya sudah siap berumah tangga. Proses pengalihan ini bersifat sementara. Namun, setelah orang tua meninggal maka harta tersebut diperhitungkan kembali sebagai harta peninggalan atau harta warisan

\section{Penunjukkan}

Penunjukan adalah proses pewarisan yang dilakukan dengan menunjuk seseorang sebagai ahli waris. Proses penunjukkan dilakukan oleh orang tua kepada anakanaknya atau pewaris kepada ahli waris. Seseorang yang ditunjuk mendapatkan harta warisan belum dapat berbuat apa-apa sebelum si pewaris wafat.

\section{Dilakukan sesudah pewaris wafat}

Proses pewarisan dapat juga dilakukan setelah si pewaris wafat. Proses pewarisan ini dilakukan dengan 2 cara. Pertama, diberikan secara langsung kepada ahli waris. Kedua, pembagian dilakukan melalui proses diskusi (waktu, juru bagi, dan cara pembagiannya). Selain itu, ada ketentuan yang harus diperhatikan sebelum harta warisan itu menjadi milik ahli waris. Ketentuan yang paling penting adalah pembagian harta warisan dilakukan berdasarkan kedudukan ahli waris dalam keluarga.

\section{Pembagian Warisan}

Pembagian harta warisan sangat diperlukan ketika pasangan, anggota keluarga, atau sanak saudara yang masih punya hubungan dekat dengan kita meninggal dunia. Dalam pembagian warisan, ada beberapa hal yang harus diperhatikan, antara lain:

a. Waktu Pembagian

Menurut adat kebiasaan yang berlaku pada adat ulun Lampung Saibatin, waktu pembagian warisan dilaksanakan setelah upacara sedekah atau nujuh hari, empat puluh hari atau saat setelah dilaksanakannya acara nyeratus hari.

\section{b. Cara Pembagian}

Pembagian ini didasarkan atas beberapa pertimbangan mengingat wujud benda dan kebutuhan ahli waris. Biasanya harta warisan yang akan di berikan susai dengan wasiat dari si pewaris. Dalam kekerabatan patrilineal, anak laki-laki anak mendapatkan jumlah warisan lebih banyak di bandingkan dengan anak perempuan. Pembagian warisan ini juga didasarkan apda kedudukan anak dalam sistem pewarisan, yakni apakah ia seabgai anak kandung, anak tiri dan anak angkat ataukah ia berstatus/kedudukan sebagai waris balu(janda).

Kedudukan anak Perempuan dalam Pewarisan pada adat ulun Lampung Saibatin 
Kedudukan mengandung arti tingkatan atau martabat keadaan yang sebenarnya, status keadaan atau tingkatan orang dan badan atau negara. Kedudukan anak laki-laki dan anak perempuan pada prinsipnya berbeda. Kedudukan perempuan dalam sistem pewarisan ulun Lampung Saibatin bukanlah sebagai ahli waris, melainkan hanya sebagai pengguna dan pemelihara warisan ketika ia masih muda. Akan tetapi, anak perempuan masih memiliki kemungkinan untuk mendapatkan bagian dari warisan tersebut apabila ia telah menikah sesuai dengan kedudukan yang ia miliki dalam keluarga, adat, dan masyarakat. Kedudukan anak perempuan dalam pewarisan, antara lain:

\section{a. Sebagai anak kandung}

Anak kandung sudah pasti akan mendapatkan hak sebagai pewaris dari orang tuanya, terutama anak laki-laki keturunan ulun Lampung Saibatin. Hal ini dikarenakan orang tua berpikir bahwa seorang anak adalah penerus dari orang tuanya. Apabila pewaris meninggal dan meninggalkan anak sulung yang usianya masih muda (kecil), maka harta warisan akan terlebih dahulu dikelola oleh kerabat dekatnya seperti paman/kakek. Ketika anak tersebut beranjak dewasa, maka hak kepemilikan atas harta dikembalikan kepada anak. Meski anak tersebut berjenis kelamin perempuan, maka anak perempuan tetap mendapatkan harta warisan penuh.

\section{b. Sebagai anak tiri dan anak angkat.}

Dalam perihal pewarisan, anak tiri dan anak angkat dimungkinkan memperoleh warisan dari orang tuanya. Kedua status anak ini memiliki yang sama yakni mendapatkan kasih sayang dan bimbingan dari orang tua angkatnya. Mengenai hal pewarisan, anak tiri dan anak angkat berhak mewarisi harta dari orang tua angkatnya. Sejalan dengan hasil penelitian yang pernah dilakukan oleh Simamora (2013) bahwa kedudukan anak perempuan sebagai anak angkat tetap memiliki hak mewaris apabila ia dalam kondisi tidak memiliki saudara laki-laki. Hal ini dilihat dari segi sosiologis dan rasa keadilan karena anak tiri/angkat telah menunaikan kewajibannya terhadap orang tua angkatnya. Berdasarkan penjelasan Bapak Faisol Amirillah, selaku punyimbang adat, bahwa pengangkatan anak bagi ulun Lampung Saibatin dimungkinkan dengan alasan sebagai berikut:

1) Keluarga tidak mempunyai anak

2) Keluarga tidak mempunyai anak laki-laki tetapi mempunyai anak perempuan

3) Keluarga yang bersangkutan akan menikahkan anaknya dengan seseorang yang bukan orang Lampung.

Keluarga yang tidak mempunyai anak dapat mengadopsi anak dari kerabat terdekat. Namun pada keluarga yang hanya memiliki anak perempuan, maka pengangkatan anak dilaksanakan saat proses perkawinan. Biasanya bentuk perkawinan yang dipakai adalah semanda. Semanda adalah bentuk perkawinan yang secara keseluruhan proses dan biayanya ditanggaung oleh pihak perempuan.

\section{c. Waris Balu (Janda)}

Sistem kekerabatan pada masyarakat patrilineal melihat kedudukan janda sebagai orang asing sehingga tidak berhak menjadi ahli waris. Sejak perkawinannya, si istri itu masuk ke dalam lingkungan atau kelompok kerabat suaminya. Begitu juga anak-anak keturunannya dari perkawinannya itu Namun, seorang istri berhak memiliki harta yang diperoleh selamanya karena ikatan perkawinan (harta bersama). Oleh sebab itulah, pada masyarakat patrilineal janda memiliki ketentuan, yaitu apabila janda diintegrasikan ke dalam kerabat suaminya, ia dapat menetap di sana dan mendapatkan nafkahnya. Perempuan janda bisa saja menjadi ahli waris apabila ada perjanjian perkawinan antara ia dengan suaminya. Jika tidak ada perjanjian kawin, seluruh harta dari suami yang meninggal termasuk harta bawaannya menjadi harta warisan si janda (istri yang hidup terlama).

\section{Jenis Harta Warisan yang diperoleh anak perempuan berdasarkan kedudukannya dalam masyarakat}

Setiap harta yang ditinggal oleh pewaris dinamakan dengan harta warisan. Harta yang diberikan bukan menyangkut tentang harta yang memiliki nilai ekonomis dan nonekonomis saja melainkan harta yang memiliki nilai religious juga. Jika wujud warisan tersebut berupa harta, ada dua jenis yang bisa dibagikan kepada ahli waris. Pertama adalah harta bergerak-berupa 
kendaraan, sertifikat deposito, dan logam mulia. Sebaliknya, kekayaan tidak bergerak berbentuk rumah, tanah, serta utang. Jenis harta warisan yang di perolehh anak perempuan marga dan anak perempuan pada umumnya dapat dilihat pada Gambar 2.

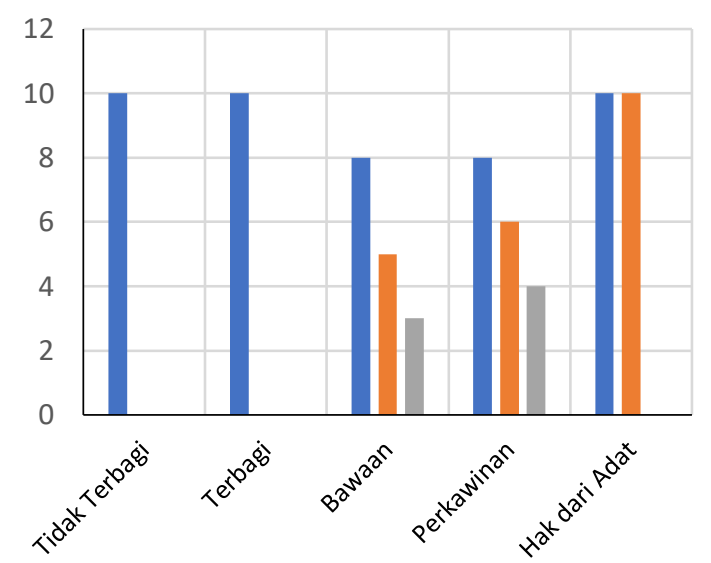

- Laki-laki Perempuan Marga Perempuanbiasa

Gambar 2. Klasifikasi Jenis Harta Warisan Ulun Lampung Saibatin

Sumber: Dokumentasi Pribadi Tahun 2020

Gambar 2, menunjukkan perbedaan jenis harta warisan yang diperoleh laki-laki, anak perempuan marga, dan anak perempuan pada umumnya. Anak laki-laki mendapatkan hampir semua jenis harta warisan, bahkan ada harta yang di peroleh secara keseluruhan seperti harta terbagi dan tidak terbagi. Hal ini dikarenakan anak laki- laki mempunyai tanggung jawab penuh untuk memelihara, membina dan mempertahankan kehidupan yang layak dari seluruh keluarga, yaitu adikadik dan orang tua yang hidup, misalnya terhadap adik-adik yang masih belum dapat berdiri sendiri seperti belum berkeluarga, masih sekolah atau sebagainya. (Zuhraini, 2017). Untuk jenis harta yang diperoleh anak perempuan, adalah seabgai berikut :

\section{1) Harta warisan anak perempuan marga}

Kedudukan yang dimiliki oleh perempuan pada lima marga yang menganut sistem kekerabatan patrilineal sekaligus informan dalam penelitian ini memposisikan ia sebagai perempuan yang wajib digugu dan ditiru oleh warganya. Apapun ia lakukan dan katakan, akan menjadi panutan bagi warganya. Berdasarkan kedudukan yang ia dapatkan sebagai keturunan marga, maka harta warisan yang ia dapatkan juga beragam. Perempuan pada marga memperoleh 2 jenis harta warisan bernilai ekonomis berupa harta bawaan dan harta perkawinan serta memperoleh hak spesial dari adat yang jenisnya berbeda dari perempuan pada umumnya.

Pada harta bawaan, yang di peroleh berupa lemari, kasur, sarung/kain, peralatan dapur dan sedikit perhiasan. Sedangkan pada harta perkawinan memperoleh berupa sebidang tanah yang akan digunakan untuk keperluan mendirikan rumah sebagai tempat tinggal keluarganya kelak.

Berbeda pada kondisi anak perempuan keturunan marga Pasar yang menganut sistem kekerabatan matrilineal, yakni perempuan yang menjadi ahli waris, memegang dan menguasai seluruh harta orang tuanya mulai dari harta materiil maupun immaterill. Hanya saja dalam pembagian warisan ini, anak laki-laki dan anak perempuan lainnya tetap mendapatkan harta warisan yang dianggap sebagai harta pemberian. Harta warisan yang ada di bagi sesuai dengan kedudukan anak dalam keluarga. Meskipun perempuan dalam marga Pasar pewarisan kedudukannya lebih tinggi, tetap yang menjalankan dan memimpin adat istiadat marga ini adalah anak laki-laki. Sehingga ia juga diberikan harta warisan berupa harta religious dan harta seperti kebun dan tanah yang di pakai untuk keberlangsungan hidup keluarga dan anak cucunya. Selain benda, harta warisan yang diperoleh anak perempuan marga berupa harta Immateril yakni perempuan marga memperolah hak-hak yang ia dapatkan sebagai perempuan adat. Hak tersebut seperti penyimpanan kain emas yang digunakan dalam proses perkawinan dan kematian adat, hak dalam menggunakan/memakai rumah adat berserta isinya dan memiliki hak dalam penggunaan tanah pemakaman adat.

\section{2) Harta warisan anak perempuan biasa/ pada umumnya \\ Berbeda halnya dengan anak perempuan} keturunan adat yang memang memiliki harta warisan berupa materill dan immaterial. Anak perempuan pada umumnya hanya mendapatkan harta yang dikumpulkan oleh orang tua selama perkawinan berupa kain sarung, lemari pakaian, tempat tidur, barang 
berharga seperti perhiasan, dan macammacam peralatan dapur. Harta pemberian orang tua ini kemudian akan dibawa oleh anak perempuan ke dalam perkawainan sehingga disebut sebagai harta bawaan. Harta Bawaan adalah semua harta warisan yang berasal dari bawaan suami dan atau bawaan istri sebelum melangsungkan perkawinan. Biasanya harta bawaan ini diperoleh anak perempuan sebelum ia menikah, dalam bahasa Lampungnya, di kenal dengan sebutan Benatok. Ada beberapa alasan mengapa kedudukan perempuan pada ulun Lampung Saibatin lebih rendah dibandingkan dengan laki-laki dalam sistem pewarisan. Alasan tersebut antara lain:

1. Kedudukan anak laki-laki khususnya anak sulung memiliki kewajiban sebagai penerus tanggung jawab dari orang tuanya untuk memenuhi setiap kebutuhan keluarganya dan merawat serta menafkahi adik-adiknya hingga dewasa.

2. Kedudukan anak perempuan dalam sistem pewarisan, meskipun ia sebagai anak kandung, anak tiri dan anak angkat juga sebagai waris balu (janda), tetap ia bukanlah sebagai ahli waris.

3. Perempuan akan menikah dan meninggalkan keluarganya atau sukunya karena dalam masyarakat adat Lampung menganut sistem eksogami yaitu harus kawin keluar dari keluarganya dan membentuk marganya sendiri.

4. Harta warisan yang diberikan kepada anak perempuan adalah sebatas harta pemberian saja, yang jenisnya di peroleh dari harta bawaan. Kedudukan perempuan adalah sebagai pengumpul harta atau tempat menyimpan harta di mana dalam pernikahan, perempuan menerima pembayaran mas kawin berupa harta yang nanti akan di bawa ke dalam pihak mempelai laki-laki.

Berdasarkan penjabaran mengenai alasan mengapa kedudukan perempuan dalam sistem pewarisan sangat berbeda dan lemah dibandingkan dengan kedudukan anak lakilaki. Seperti yang di paparkan oleh Muzainah (2012) bahwa besaran bagian masingmasing ahli waris seharusnya tidak didasarkan kepada gender, melainkan didasarkan kepada kondisi objektif tentang harta peninggalan dan kontribusi ahli waris terhadap pewaris. Oleh karena itu besarnya bagian perempuan bersifat relative, yaitu bisa lebih besar dari laki-laki, bisa lebih kecil dari laki-laki dan atau bisa sama dengan lakilaki. Meskipun perempuan ulun Lampung mengetahui dengan jelas ketidaksamaan dalam hal pewarisan ini, namun mereka tetap masih menjunjung tinggi adat istiadat dan kebiasaan-kebiasaan yang telah turun temurun dan sudah mengkristal puluhan tahun di daerah Pesisir Tengah. Hal ini karena adanya pengaruh Hukum Islam yang kuat khususnya dalam hukum waris. Mayoritas masyarakat Pesisir Tengah adalah beragama Islam, menurut Hukum Waris Islam bagian anak laki-laki dan perempuan adalah tidak sama, yaitu laki-laki berhak atas 2 (dua) bagian sedangkan anak perempuan satu bagian.

Jika di lihat dari satu sisi keadilan, khususnya dalam hal kedudukan antara lakilaki dan perempuan terlebih pada zaman/era modernisasi, dan emansipasi sekarang ini hal tersebut dianggap tidak cocok dan sesuai lagi. Tetapi kalau di lihat latar belakang ataupun alasan dari perbedaan perlakuan atau diskriminasi terhadap anak perempuan tersebut maka akan dapat memakluminya. Logikanya adalah karena dengan perkawinannya anak perempuan itu, dia anggap sudah bukan anggota kerabat lagi, dia sudah dilepaskan ikatannya oleh calon suaminya dengan suatu pembayaran yang disebut jujur yang sekaligus memutus hubungan kekerabatannya. Dan karena sudah bukan anggota kerabat lagi, maka anak perempuan tadi tidak dapat/berhak atas harta warisan. Tetapi dalam prakteknya dan juga karena adanya rasa ketidakpuasan atas sistem hukum waris tersebut, dapat terjadi seorang ayah pada waktu masih hidupnya memberikan/menghibahkan kepada anak perempuannya sebidang tanah pertanian atau ternak, baik kepada anak perempuan yang tak kawin maupun yang akan kawin.

Oleh karena itu, untuk menyamakan kedudukan antara perempuan dan laki-laki pada ulun Lampung Saibatin juga memiliki harta kekayaan yang sama, perempuan dapat melakukan dua cara, yaitu Ascribed status dan Achieved Status

a. Ascribed status

Ascribed status adalah status sosial seseorang yang sudah ada dari lahir. Umumnya, status sosial ini disebabkan oleh garis keturunan dari individu tersebut. Status 
sosial yang termasuk kedalam ascribed status antara lain adalah jenis kelamin, ras, kasta, golongan, keturunan, suku serta gelar yang didapatkan. Anak perempuan ulun Lampung Saibatin yang merupakan keturunan adat memiliki gelar adat sebagai berikut:

1) Ghatu, adalah gelar penghabisan adat Lampung yaitu gelar adat tertinggi, gelar ini didapat oleh seseorang yang berkedudukan tinggi dalam keluarga dan keturunan tersebut. Gelar ini akan diperoleh apabila anak perempuan menikah dengan anak laki-laki tertua dalam adat ulun Lampung Saibatin. Seorang Ghatu dalam adat dijadikan sebagai tutukan (teladan) bagi masyakat adatnya. Seperti hal nya dalam proses perkawinan dilakukan oleh warga, posisi seorang ghatu akan sama tinggi nya dengan pengantin. Ia akan duduk sejajar dengan pengantin, pada kursi/tempat duduk yang berhadapan atau bersebelahan.

2) Ina dalom adalah gelar perempuan yang merupakan istri dari dalam atau gelar kepada anak perempuan tertua yang hubungannya adalah anak kandung dalam keluarga. Kedudukan yang di perolehnya ini berhubungan dengan kewajiban ia dalam proses umbumbak (proses pemasangan alat/bahan pelaminan pernikahan), dimana hanya keturunan marga adat saja yang berhak melakukan umbumbak tersebut yakni Ina Dalom dan Batin.

3) Batin adalah gelar dibawah dalom yaitu gelar adat yang kedudukannya sebagai Istri dari Raja/Pangeran. Gelar ini juga dapat disematkan kepada anak perempuan nomor dua yang hubungannya adalah anak kandung dalam keluarga. Dalam adat ulun Lampung Saibatin, Batin memilki hak dalam penyimpanan dan merawat alat/bahan pelaminan perkawinan.

4) Raden, adalah gelar dibawah batin, yaitu gelar adat dengan tingkatan ketiga yang kedudukannya di bawah batin. Kedudukan Radin dalam adat berperan sebagai punggawa (pengawal) yang memegang peralatan atau benda-benda pusaka dalam prosesi adat seperti pemegang tobak, pedang, bendera dan lain-lain serta berkewajiban menyimpan, menjaga dan memelihara harta warisan pusaka.

5) Minak adalah gelar dibawah raden yaitu gelar adat yang kedudukannya di bawah raden atau gelar yang didapatkan oleh anak yang berkedudukan sebagai anak bungsu dalam keluarga. Anak perempuan yang berkedudukan sebagai Minak bertugas sebagai pelaksana kegiatan acara di bagian dapur. Peran minak tentu lebih nyata dan lebih di butuhkan mengingat bahwa pada pelapisan bawah inilah yang bekerja keras dalam menyukseskan kegiatan atau acara adat. Segala kekurangan tentang pangan, di atur dan dilaksanakan oleh minak.

Gelar adat yang dimaksudkan di atas, merupakan gelar khusus yang diberikan adat kepada anak perempuan yang mana di peroleh secara otomatis ketika ia datang kesebuah keluarga sebagai menantu dan menjadi bagian dari keluarga tersebut. Dengan status/kedudukan itu juga secara otomatis harta suami juga menjadi harta-nya, meskipun hanya sebatas pemakai dan pelestari saja. Disamping itu, anak perempuan biasa (pada umunya) juga memperoleh gelar, hanya saja gelar yang diberikan memiliki hak yang berbeda dengan gelar yang diberikan adat. Bisanya gelar yang diberikan sesuai dengan adok/gelar/panggilan berdasarkan kedudukannya di dalam keluarga, seperti Udo, Uwo, Ngah, Cik, dan Uncu. Perbedaan dalam pemberian gelar ini adalah pada hak dan kewajiban anak perempuan dalam keluarga dan marga adat ulun Lampung Saibatin.

\section{b. Achieved Status}

Achieved Status merupakan jenis status sosial yang dapat dimiliki oleh seseorang dalam lingkungan hidupnya tetap tidak didapatkan sejak ia lahir. Status tersebut dapat diperoleh lewat kerja keras, dan perjuangan. Achieved status bersifat terbuka bagi siapa saja, dalam artian, siapa saja dapat mengejar achieved status ini. Ada beberapa hal yang dapat dijadikan sebagai tolak ukur sebuah kedudukan yang dapat diperoleh oleh seseorang dalam sebuah lingkungan masyarakat melalui usaha atau kerja keras yang ia lakukan antara lain:
1) jabatan,
2) pendidikan 
3) kekayaan.

Penggolongan ini dapat didasarkan pada banyak sudut pandang, salah satunya ekonomi. Status/kedudukan ini, diperoleh seseorang melalui usaha yang disengaja terlebih dahulu. Untuk memperoleh status ini, seseorang harus melalui perjuangan yang panjang dengan memerlukan pengorbanan dan tergantung dari kemampuan masing masing dalam mengejar serta mencapai tujuannya.

Kedudukan sosial individu di lingkungan masyarakat yang mampu didapat dengan kerja keras pasti akan membutuhkan pengorbanan dalam pencapaiannya. Semakin tinggi status sosial/kedudukan yang dimiliki seseorang, maka semakin tinggi pula penghargaan masyarakat terhadap diri mereka. Oleh karenanya, upaya untuk mendapat status sosial yang tinggi terus dilakukan oleh masyarakat.

\section{Kesimpulan}

Mengenai kedudukan perempuan dalam sistem pewarisan menurut hukum adat yang berlaku pada ulun Lampung Saibatin, dapat di simpulkan bahwa pada dasarnya kedudukan anak perempuan sangatlah lemah dibandingkan dengan kedudukan anak lakilaki. Dalam pewarisan anak perempuan bukanlah sebagai ahli waris meskipun ia dalam keluarga memiliki status atau kedudukan sebagai anak kandung, anak tiri dan anak angkat atau sebagai waris balu (janda).

Kedudukan pada anak perempuan tersebut berdampak pada jenis harta warisan yang diperolehnya. Ada dua jenis harta yang diperoleh anak perempuan yang merupakan keturunan marga yakni harta materiil dan immateriil. Harta materiil berupa harta bawaan dan harta perkawinan sedangkan harta immateriil berupa hak yang didapat dari masyarakat. Sedangkan anak perempuan biasa atau perempuan pada umumnya hanya memperoleh harta berupa materiil saja dengan jenis harta bawaan dan harta perkawinan. Yang menjadi pembeda antara perempuan marga dengan perempuan biasa adalah pada harta imaaterill.

Dari lemahnya kedudukan tersebut yang berdampak pada jenis harta warisan yang diperoleh, maka untuk menyamakan kedudukan dan untuk memiliki harta sendiri, anak perempuan harus mendapatkan dan memperolehnya dengan 2 cara yaitu ascribed status dan achieved status.

\section{Referensi}

Bungin. 2012. Analisis Data Penelitian kualitatif. Jakarta: PT Raja Grafindo Persada.

Haar,Ter. 1990. Asas-Asas dan Susunan Hukum Adat, Terjemahan R. Ng Surbakti Presponoto, Let. N., Bandung: Voricin Vahveve.

Hadikusuma, Hilman. 2003. Hukum Waris Adat. Citra Aditya Bakti: Bandung.

Huberman, A. Maicel and B Miles Mathew. 1992. Qualitative data Analysis, Edisi Bahasa Indonesia, UII Press: Jakarta.

Muzainah, Gusti. 2012. Prinsip prinsip hukum kedudukan perempuan dalam hukum waris adat masyarakat Banjar. Jurna Jurnal Ilmu Hukum Fakultas Syariah dan Ekonomi Islam Vol. 8 (15). Hal. 10 - 19.

Nugroho, Sigit Sapto. 2016. Hukum Waris Adat di Indonesia. Solo: Pustaka Iltizam

Simamora, Katrin. 2013. Kedudukan Anak Perempuan Dalam Hukum Waris Adat Masyarakat Batak Toba di Kota Pontianak Yang Tidak Mempunyai Saudara LakiLaki. Jurnal Hukum Gloria Yuris. Vol. 1 (2).

Sakina, Ade Irma \& Dessy Hasanah Siti A. 2019. Menyoroti Budaya Patriarki Di Indonesia. Jurnal Social Work. Vol 7 (1).

Soepomo. 1980. Kedudukan Hukum Adat di Kemudian Hari. Pustaka Rakyat: Jakarta.

Zuhraini. 2017. Perempuan dan Hukum Dalam Masyarakat Hukum Adat Lampung Saibatin. Jurnal Pengembangan Masyarakat Islam. Vol 10 (2). 